\title{
Changing trends in cytomegalovirus retinitis with triple therapy
}

\begin{abstract}
Purpose Cytomegalovirus retinitis (CMVR) has been the most common cause of visual loss in AIDS patients. We investigate whether the pattern of disease has changed since the introduction of triple therapy.

Methods We reviewed the records of all patients with CMVR in one teaching hospital HIV unit over a 2 year period $(n=24)$. This included the ophthalmic and systemic findings, HIV and CMV treatment, survival after diagnosis and CD4 results.

Results There has been a marked decrease in the number of patients developing new CMVR: from 21 eyes (15 patients) to 4 eyes (4 patients) in two consecutive 12 month periods between January 1996 and December 1997, coinciding with the introduction of triple therapy in October 1996. Median survival has increased from 376 days in the deceased patients to 598 days in the survivors on triple therapy. Median time to CMVR relapse has lengthened from 79 to 179 days in the triple therapy cohort. The pattern of ocular morbidity in the 11 eyes of the 7 surviving patients is also changing, with no new zone 1 disease, and a marked rise in the incidence of uveitis, maculopathy and cataracts.

Conclusion Results suggest that triple therapy is associated with an increase in survival, a decrease in CMVR relapse and changes in ocular features. This transition has implications for current screening and treatment protocols.
\end{abstract}

Key words AIDS, CMV retinitis, Cytomegalovirus, HAART, HIV, Protease inhibitor, Triple therapy

Cytomegalovirus retinitis (CMVR) is the leading cause of visual loss in patients with AIDS. The lifetime risk for CMVR is $25-45 \%$ in AIDS patients as they approach the terminal stages of their disease (when the CD4 count drops to below 50 cells $\left./ \mathrm{mm}^{3}\right)$. ${ }^{1}$ The median survival from the diagnosis of CMVR in previous studies ranged from 8.5 to 12.4 months. ${ }^{2}$ Despite the use of aggressive virostatic
VICKIE LEE, IAN SUBAK-SHARPE, SANJAY SHAH, CELIA AITKEN, SIMON LIMB, ANTHONY PINCHING treatment, the rate of relapse and inexorable progression increases with each subsequent attack, with the development of viral resistance and the decline of the patient's immune function.

With the advent of triple therapy (using a combination of two reverse transcriptase inhibitors and one protease inhibitor), some patients have had their HIV-RNA viral load significantly reduced and CD4 counts boosted to over 100 cells $/ \mathrm{mm}^{3}$. This partial restitution of immune function appears to have resulted in a clear benefit in patient survival and a decrease in the number of opportunistic infections. ${ }^{3}$

This study reports on our experience of the ocular manifestations of AIDS over a 2 year period in one HIV unit (total patient population at the conclusion of the study of 480 , with more than 180 patients currently on triple therapy) from January 1996 to December 1997. Triple therapy was introduced in October 1996.

\section{Patients and methods}

All the records of patients with AIDS-related CMVR seen at St Bartholomew's Hospital between January 1996 and December 1997 were reviewed. Data collected included date of diagnosis of AIDS and CMVR; dates, number and extent of reactivations; details of systemic and intravitreal anti-CMV therapy; best corrected Snellen visual acuity; and ocular features including cataract, uveitis, maculopathy and retinal detachment. The extent of CMVR was assessed from fundal photographs and classified according to a standard protocol. ${ }^{2}$ Concurrent opportunistic infections, timing and details of anti-retroviral treatment, CD4 counts and viral load were also noted.

From October 1996 triple therapy consisting of one protease inhibitor and two nucleoside analogues was commenced in patients with a low or decreasing CD4 count $\left(<350\right.$ cells $\left./ \mathrm{mm}^{3}\right)$, a high or rising viral load ( $>10000$ copies $/ \mathrm{ml}$ ), new opportunistic infections, or according to patient desire to start the treatment regimen. CD4 count and viral load were monitored 3
V. Lee

I. Subak-Sharpe

S.M. Shah

Department of

Ophthalmology

St Bartholomew's Hospital London, UK

C. Aitken

Department of Virology

St Bartholomew's Hospital London, UK

S. Limb

A. Pinching

Department of Infection \& Immunity

St Bartholomew's Hospital London, UK

Mr Sanjay Shah, FRCOphth

Department of Ophthalmology

St Bartholomew's Hospital West Smithfield

London EC1A 7BE, UK

Tel: +44(0)1716017158

Fax: +44 (0)1716017863

Presented as a paper at the Tenth Anniversary Congress of the Royal College of Ophthalmologists, Glasgow, 1998

Received: 14 July 1998

Accepted in revised form:

25 November 1998 
monthly and therapeutic success was judged by a rising CD4 count and a decreasing viral load (<400 copies / $\left.\mathrm{mm}^{3}\right)$.

\section{Results}

Twenty-four patients (38 eyes) with CMVR were seen in the HIV eye clinic between January 1996 and December 1997. We analysed all our results with regard to the use of triple therapy, resulting in two cohorts of patients: the non-TT cohort consisting of 15 patients (23 eyes) who never received triple therapy or who were on triple therapy for less than 3 months before death; and the TT cohort of 9 patients (15 eyes) who received triple therapy for more than 3 months. The latter group was also analysed with regard to rates of relapse during the periods before and after triple therapy. There were 7 survivors (11 eyes) at the conclusion of the study.

There were 23 men and 1 woman. The median age at presentation was 36.5 years (range $29-45$ years). Of these patients 19 were male homosexuals, 1 woman and 1 man were heterosexual, 2 were from endemic areas in Africa, and 1 received contaminated blood products in Africa. The median follow-up time was 323 days (range 30-901 days).

The prevalence of CMVR was 33 eyes (19 patients) in the 12 month period between January 1996 and December 1996 and 12 eyes (7 patients) between January 1997 and December 1997, respectively. The incidence of new CMVR was 21 eyes (15 patients) in the first 12 month period and 4 eyes (4 patients) in the second 12 month period. There were no new cases seen in patients who had been on triple therapy for more than 3 months.

Ten patients (41.6\%) had extraocular CMV preceding the diagnosis and had undergone previous treatment with ganciclovir. This included oesophagitis, gastritis, duodenitis, colitis, cholangitis and encephalitis.

\section{Initial findings}

Four of twenty-four (16.6\%) patients had bilateral disease at first presentation. An additional 10 patients developed CMVR in the contralateral eye during follow-up, making a total of $14(58.3 \%)$ patients with bilateral ocular involvement. No patient developed new bilateral disease after commencing triple therapy. The median visual acuity (VA) at presentation was $6 / 9$ (range 6/5 to hand movements), with 2 patients presenting with retinal detachment at first visit. Five eyes had zone 1 disease at presentation. At initial diagnosis, 10 (41.6\%) patients were asymptomatic, with 7 complaining of floaters and photopsia, 3 of scotomas and 4 of visual loss.

\section{Survival and concurrent diseases}

During the course of follow-up, 16 patients (66.7\%) died: 15 from AIDS-related diseases and 1 from suicide. One patient was lost to follow-up after 1 month. The latter 2 patients were excluded from the survival analysis. Median survival after CMVR diagnosis in the dead cohort was 376 days (range 77-901 days) compared with the cohort of 7 survivors who have survived a median of 598 days from CMVR diagnosis (range 110-731 days) at the last follow-up visit. Two of the seven survivors were already being treated with triple therapy at the time of CMVR diagnosis, and the remaining 5 were changed onto triple therapy. There were 15 deaths ( 1 from suicide) in the non-TT $(100 \%)$ cohort and 2 deaths in the TT cohort. The median time on triple therapy in the TT group was 12 (range 5-15) months.

All patients had concurrent AIDS-associated disease. Twelve patients had Pneumocystis carinii pneumonia, 16 had oral candidiasis, 9 had mycobacterial infections, 8 had Kaposi's sarcoma, 3 had high-grade non-Hodgkin's lymphoma and 10 had extraocular CMV preceding the diagnosis of CMVR.

\section{CMVR reactivations}

The median time to relapse in all patients was 69 days. The median time to first relapse was 130 days. The median time to relapse in the non-TT group was 47 days, and 85.5 days in the TT group. In the TT group the median time to reactivation before triple therapy was 79 days and 179 days following triple therapy. The median period of inactivity from last reactivation to last followup visit/death in the TT group was 202 days.

\section{Treatment}

The treatment of CMVR was according to a standard regimen. ${ }^{2}$ Patients were induced with either intravenous ganciclovir or foscarnet or a combination of both and maintained on one drug only. Since early 1997 intravenous cidofovir has been used in resistant cases or in patients who were unable to tolerate foscarnet or ganciclovir. Most patients required changes of treatment due to development of viral resistance during the course of the disease. Six patients received cidofovir. Eight patients received oral ganciclovir maintenance. Seven patients received intravitreal injections of ganciclovir ( $2 \mathrm{mg} / 0.1 \mathrm{ml}$ ) with a median of 2 per eye (range 1-10). One patient had an insertion of a ganciclovir sustainedrelease device. No patient developed ocular hypotony. None had received intravitreal cidofovir.

\section{Visual loss}

During the study period 2 patients ( 2 eyes) presented with a visual acuity of $<6 / 18$ in the affected eye and 13 patients (19 eyes) went on to develop significant visual loss (defined as the loss of 2 or more lines of best corrected Snellen acuity). The causes of visual loss according to triple therapy status were as follows: Before triple therapy 10 patients (12 eyes) had significant visual loss from a combination of retinal detachment, zone 1 disease and maculopathy. After triple therapy, 3 patients (5 eyes) had significant visual loss from cataracts and maculopathy. 


\begin{tabular}{|c|c|c|c|c|c|c|c|c|c|c|c|}
\hline $\begin{array}{l}\text { Patient } \\
\text { no. }\end{array}$ & Sex & $\begin{array}{c}\text { Age at } \\
\text { diagnosis } \\
\text { (years) }\end{array}$ & $\begin{array}{l}\text { Risk } \\
\text { factors }\end{array}$ & Bilateral & $\begin{array}{l}\text { Survival } \\
\text { after } \\
\text { diagnosis } \\
\text { (days) }\end{array}$ & $\begin{array}{c}\text { Treatment } \\
\text { of } \\
\text { CMVR }\end{array}$ & $\begin{array}{c}\text { Initial } \\
\text { VA }\end{array}$ & $\begin{array}{c}\text { Final } \\
\text { VA }\end{array}$ & $\begin{array}{l}\text { Time to } \\
\text { VA loss } \\
\text { (months) }\end{array}$ & $\begin{array}{l}\text { Zone } 1 \\
\text { disease }\end{array}$ & $\begin{array}{l}\text { Ocular } \\
\text { features }\end{array}$ \\
\hline \multirow[t]{2}{*}{1} & \multirow[t]{2}{*}{ M } & \multirow[t]{2}{*}{34} & \multirow[t]{2}{*}{ Ho } & \multirow[t]{2}{*}{ Yes } & \multirow[t]{2}{*}{194} & \multirow[t]{2}{*}{$\mathrm{G}, \mathrm{F}, \mathrm{OG}$} & $6 / 6$ & $6 / 12$ & & Yes & \\
\hline & & & & & & & $6 / 6$ & $6 / 18$ & 6 & Yes & \\
\hline 2 & M & 38 & Ho & No & 727 & G, F & $6 / 9$ & $\mathrm{CF}$ & 6 & Yes & RD \\
\hline \multirow[t]{2}{*}{4} & \multirow[t]{2}{*}{$\mathrm{M}$} & \multirow[t]{2}{*}{29} & \multirow[t]{2}{*}{ Ho } & \multirow[t]{2}{*}{ Yes } & \multirow[t]{2}{*}{285} & \multirow[t]{2}{*}{$\mathrm{G}, \mathrm{F}, \mathrm{OG}$} & $6 / 9$ & $\mathrm{HM}$ & \multirow[t]{2}{*}{7} & \multirow[t]{2}{*}{ Yes } & \multirow[t]{2}{*}{$\mathrm{RD}(2)$} \\
\hline & & & & & & & $6 / 9$ & $6 / 18$ & & & \\
\hline 5 & $\mathrm{M}$ & 34 & Ho & No & 418 & G, F & $6 / 18$ & PL & 13 & Yes & RD \\
\hline 6 & $\mathrm{M}$ & 47 & Ho & Yes & 692 & G, F, OG & $6 / 9$ & $6 / 9$ & - & Yes & \\
\hline \multirow[t]{2}{*}{7} & \multirow[t]{2}{*}{ M } & \multirow[t]{2}{*}{35} & \multirow[t]{2}{*}{ Ho } & \multirow[t]{2}{*}{ Yes } & \multirow[t]{2}{*}{77} & \multirow[t]{2}{*}{ G } & $6 / 6$ & $6 / 6$ & \multirow[t]{2}{*}{ - } & \multirow[t]{2}{*}{ No } & \\
\hline & & & & & & & $6 / 24$ & $6 / 24$ & & & \\
\hline \multirow[t]{2}{*}{8} & \multirow[t]{2}{*}{$\mathbf{M}$} & \multirow[t]{2}{*}{32} & \multirow[t]{2}{*}{ E } & \multirow[t]{2}{*}{ Yes } & \multirow[t]{2}{*}{150} & $\mathrm{G}, \mathrm{OG}, \mathrm{C}$ & $6 / 6$ & $6 / 6$ & 3 & Yes & Maculopathy \\
\hline & & & & & & & $6 / 9$ & $6 / 36$ & & & (1) \\
\hline 9 & $\mathrm{M}$ & 38 & Ho & Yes & 96 & G & $6 / 6$ & $6 / 9$ & - & No & \\
\hline & & & & & & & $6 / 6$ & $6 / 9$ & & & \\
\hline 10 & M & 34 & $\mathrm{He}$ & Yes & 95 & $G, F, C$ & $6 / 6$ & $6 / 6$ & - & No & \\
\hline & & & & & & & $6 / 6$ & $6 / 9$ & & & \\
\hline 11 & M & 39 & Ho & Yes & 594 & $G, F$ & $6 / 6$ & $6 / 12$ & & & Maculopathy \\
\hline & & & & & & & $6 / 6$ & $6 / 60$ & 16 & Yes & (1) \\
\hline 15 & $\mathrm{M}$ & 37 & Ho & No & Lost to $\mathrm{f} / \mathrm{u}$ & G & $6 / 12$ & Lost to $\mathrm{f} / \mathrm{u}$ & - & & \\
\hline 17 & $\mathbf{M}$ & 45 & Ho & No & 334 & $G, F, C$ & $6 / 6$ & $6 / 6$ & - & No & \\
\hline 19 & $\mathrm{~F}$ & 38 & $\mathrm{He}$ & No & 450 & G, OG & HM & HM & - & & Total RD \\
\hline 20 & M & 31 & Ho & No & 149 & G & $6 / 6$ & $6 / 6$ & - & No & \\
\hline 21 & M & 45 & Ho & No & 901 & $\begin{array}{c}\text { G, F, OG, } \\
\text { IG }\end{array}$ & $6 / 6$ & $6 / 18$ & 18 & Yes & $\begin{array}{l}\text { Uveitis, RD, } \\
\text { maculopathy }\end{array}$ \\
\hline
\end{tabular}

Note: only affected eyes are shown.

VA, visual acuity; Ho, homosexual contact; E, endemic HIV spread; He, heterosexual contact; f/u, follow-up; G, intravenous ganciclovir; F, intravenous foscarnet; OG, oral ganciclovir; IG, intravitreal ganciclovir; C, intravenous cidofovir; RD, retinal detachment.

${ }^{\mathrm{a}} \mathrm{VA}$ loss is the loss of 2 or more lines of Snellen acuity.

Nineteen $(79 \%)$ patients in the total cohort had an acuity of $6 / 12$ or better in the better eye. In the non-TT cohort no patient had a visual acuity of $6 / 60$ or worse in the better eye at death. At last follow-up in the TT cohort, 2 of the 7 surviving patients had a visual acuity of $6 / 60$ or worse in the better eye. One of the survivors became legally blind before commencing triple therapy.

\section{Ocular features}

Nine of the 14 patients (64\%) with bilateral disease had zone 1 involvement. Of these, 6 had bilateral zone 1 involvement. Only 2 of the 10 patients (20\%) with unilateral disease had zone 1 involvement. There was no new zone 1 disease after triple therapy.

Before triple therapy, 6 patients ( 7 eyes) developed retinal detachment. There was one case of retinal detachment after triple therapy. Before triple therapy there were 3 patients ( 3 eyes) with maculopathy, and 6 patients (10 eyes) developed maculopathies after triple therapy. In 4 patients with bilateral maculopathies there was associated uveitis. None of these patients had received rifabutin. The time course of the development of uveitis after initiation of triple therapy in the 4 patients with anterior uveitis and vitritis was 2, 3, 6 and 11 months.

\section{Use of cidofovir}

The initroduction of cidofovir into the treatment regimen also complicates the clinical picture. ${ }^{4-6}$ Of the 7 patients who received intravenous cidofovir, one developed bilateral anterior uveitis requiring long-term topical steroid treatment and eventually developed bilateral cataracts requiring surgery in both eyes. ${ }^{1}$

\section{CD4 counts}

All our patients had CD4 counts of less than 50 cells/ $\mathrm{mm}^{3}$ at diagnosis of CMVR. In the non-TT group the CD4 count remained at this level until death. In the TT cohort after triple therapy, 6 patients had a CD4 count that remained persistently below 50 cells $/ \mathrm{mm}^{3}$. Three patients had a CD4 count boosted beyond 100 cells $/ \mathrm{mm}^{3}$, and of these two were above 150 cells $/ \mathrm{mm}^{3}$.

\section{Discussion}

CMVR is the commonest opportunistic ocular infection in AIDS patients in the era of Pneumocystis prophylaxis. ${ }^{1}$ It is also the most substantial cause of visual morbidity in AIDS. This study chronicles the ophthalmic experience of one HIV unit undergoing the transition to triple therapy. We attempt to provide a 'snapshot' of all CMVR patients seen over a 2 year period in the HIV eye clinic. We have seen an increase in patient survival and time to CMVR 


\begin{tabular}{|c|c|c|c|c|c|c|c|c|c|c|c|c|}
\hline $\begin{array}{l}\text { Patient } \\
\text { no. }\end{array}$ & Sex & $\begin{array}{l}\text { Age at } \\
\text { diagnosis } \\
\text { (years) }\end{array}$ & $\begin{array}{l}\text { Risk } \\
\text { factors }\end{array}$ & Bilateral & $\begin{array}{l}\text { Survival } \\
\text { after } \\
\text { diagnosis } \\
\text { (days) }\end{array}$ & $\begin{array}{l}\text { Treatment } \\
\text { of CMV }\end{array}$ & $\begin{array}{l}\text { Initial } \\
\text { VA }\end{array}$ & $\begin{array}{l}\text { Final } \\
\text { VA }\end{array}$ & $\begin{array}{l}\text { Time to } \\
\text { VA loss } \\
\text { (months) }\end{array}$ & $\begin{array}{l}\text { Zone } 1 \\
\text { disease }\end{array}$ & $\begin{array}{l}\text { Ocular } \\
\text { features }\end{array}$ & $\begin{array}{c}\text { Time } \\
\text { on } \\
\text { TT } \\
\text { (months) }\end{array}$ \\
\hline $3^{\mathrm{b}, \mathrm{c}}$ & $\mathrm{M}$ & 31 & Ho & Yes & 616 & $G, F, V$ & $\begin{array}{l}6 / 9 \\
6 / 9\end{array}$ & $\begin{array}{l}\mathrm{HM} \\
\mathrm{CF}\end{array}$ & 4 & Yes & Maculopathy (1) & 13 \\
\hline 12 & M & 39 & Ho & Yes & 594 & $\begin{array}{l}\text { G, C, OG, } \\
\text { F, IG }\end{array}$ & $\begin{array}{l}6 / 9 \\
6 / 9\end{array}$ & $\begin{array}{l}6 / 18 \\
6 / 60\end{array}$ & 15 & Yes & $\begin{array}{c}\text { Uveitis (2), } \\
\text { maculopathy (2) }\end{array}$ & 11 \\
\hline $13^{\mathrm{b}}$ & M & 41 & Ho & Yes & 731 & G, F, IG & $\begin{array}{l}6 / 6 \\
6 / 6\end{array}$ & $\begin{array}{l}6 / 18 \\
6 / 18\end{array}$ & 21 & No & $\begin{array}{c}\text { Uveitis (2), } \\
\text { maculopathy (2) }\end{array}$ & 8 \\
\hline $14^{\mathrm{b}}$ & M & 45 & Ho & Yes & 531 & G, F, OG, IG & $\begin{array}{l}6 / 6 \\
6 / 6\end{array}$ & $\begin{array}{l}6 / 12 \\
6 / 9\end{array}$ & & No & $\begin{array}{c}\text { Cataract (2), } \\
\text { uveitis (2), } \\
\text { maculopathy (2), } \\
\text { RD (1) }\end{array}$ & 13 \\
\hline $16^{b}$ & M & 32 & B & No & 598 & G, F, C, IG & $6 / 9$ & $6 / 18$ & 13 & No & Maculopathy & 12 \\
\hline $18^{\mathrm{c}}$ & M & 36 & Ho & Yes & 309 & G, F, C, IG & $\begin{array}{l}6 / 6 \\
6 / 60\end{array}$ & $\begin{array}{l}6 / 36 \\
6 / 60\end{array}$ & 10 & Yes & RD & 7 \\
\hline $\begin{array}{l}22^{\mathrm{b}} \\
23^{\mathrm{b}}\end{array}$ & $\begin{array}{l}\mathrm{M} \\
\mathrm{M}\end{array}$ & $\begin{array}{l}44 \\
34\end{array}$ & $\begin{array}{c}\text { E } \\
\text { Ho }\end{array}$ & $\begin{array}{l}\text { No } \\
\text { No }\end{array}$ & $\begin{array}{l}312 \\
110\end{array}$ & $\begin{array}{l}\text { G } \\
G\end{array}$ & $\begin{array}{l}6 / 6 \\
6 / 6\end{array}$ & $\begin{array}{l}6 / 6 \\
6 / 6\end{array}$ & & $\begin{array}{l}\text { No } \\
\text { No }\end{array}$ & & $\begin{array}{r}15 \\
5\end{array}$ \\
\hline $24^{\mathrm{b}}$ & M & 34 & $\mathrm{He}$ & Yes & 620 & G, F, C, IG & $\begin{array}{l}6 / 6 \\
6 / 6\end{array}$ & $\begin{array}{l}\text { CF } \\
6 / 60\end{array}$ & & No & $\begin{array}{c}\text { Cataract (2), } \\
\text { maculopathy (2), } \\
\text { uveitis (2) }\end{array}$ & 13 \\
\hline
\end{tabular}

Note: only affected eyes are shown.

Ho, homosexual contact; He, heterosexual contact; B, infected blood products; E, endemic HIV spread; G, intravenous ganciclovir; $\mathrm{F}$, intravenous foscarnet; OG, oral ganciclovir; IG, intravitreal ganciclovir; C, intravenous cidofovir; V, ganciclovir implant (Vitrasert). $\mathrm{RD}$, retinal detachment.

${ }^{a}$ VA loss is the loss of 2 or more lines of Snellen visual acuity.

bSurvivor at last follow-up.

${ }^{\mathrm{c}}$ Visual loss preceding triple therapy.

relapse and a shift in the pattern of ocular features from zone 1 disease and retinal detachments to that of uveitis and its sequelae. The simultaneous decrease in bilateral disease and zone 1 disease in patients after triple therapy may be related ${ }^{8}$ and reflects the general improvement in immune function.

\section{Cost of triple therapy}

The increased cost of triple therapy appears to be justified by the results reported in a recent multicentre study, which shows substantial health and cost benefits enjoyed by the early adopters of triple therapy as morbidity and mortality have been cut. ${ }^{3}$ This argues for the extensive use of triple therapy in HIV disease.

\section{Questions raised by widespread use of triple therapy}

The questions facing most ophthalmologists managing HIV disease include the visual prognosis with increased survival and implications for the current CMVR screening and treatment protocol.

\section{Increase in inflammatory eye disease and visual prognosis}

The rise in the rates of uveitis may be attributed to many causes. ${ }^{9}$ Magone et al $^{10}$ documented a progressive breakdown of the blood-ocular barrier with time in HIV patients which is accelerated by the presence of active
CMVR. There is no evidence that any of our patients had ocular syphilis ${ }^{11}$ or herpes zoster. ${ }^{12}$ A plausible explanation offered by Zegans et al. ${ }^{24}$ is that increased immunocompetence alone causes an inflammatory response to the CMV antigens that was previously impossible in the profoundly immunosuppressed. However, the CD4 count in all of our 4 patients with bilateral uveitis remained below 100 cells $/ \mathrm{mm}^{3}$ at the onset of the vitritis. Two of these patients who developed bilateral cystoid macular oedema did not previously have zone $1 \mathrm{CMVR}$, unlike the cohort described by Silverstein et al. ${ }^{13}$

The new issue is the management of complicated uveitis with old CMV scarring, secondary cataract and maculopathies. A recent study has quoted an anterior uveitis rate of $44 \%$ in patients receiving intravenous cidofovir. ${ }^{14}$ The management of uveitis and its sequelae in immunocompromised (and often renal-impaired) patients is difficult, as systemic steroids and acetazolamide must be used with caution. Also decisions regarding cataract surgery with coexisting macular pathology can be difficult. Given that patient survival has increased, more patients are becoming significantly visually impaired. Our study is consistent with other studies in that most patients retain functional vision at death in one eye. ${ }^{15}$ However, of the 7 survivors, 1 patient has lost 2 lines of best corrected Snellen visual acuity from bilateral cystoid macula oedema, and 2 have a 
visual acuity of less than $6 / 60$ in the better eye - resulting from old zone 1 disease in 1 patient and from cataracts and inflammatory maculopathy in the other.

\section{Implications for the screening of CMVR}

The fall in the incidence of new CMVR is similar to that reported by Jabs et al., ${ }^{16}$ who found a decline in the incidence of CMVR in Baltimore by $55 \%$ over the past 3 years. CMVR relapses have been considerably reduced since the use of triple therapy, with the median time of progression rising from 79 to 179 days in our TT cohort.

The strongest independent risk factor for the development of CMVR previously has been the CD4 count, ${ }^{17}$ as effective immune response to CMVR is mainly cell-mediated. Triple therapy/highly active antiretroviral therapy (HAART) increases CD4 cell numbers by reducing viral replication. The average CD4 count after triple therapy is $100-150$ cells $/ \mathrm{mm}^{3}$ (compared with $>500$ cells $/ \mathrm{mm}^{3}$ in non-immunocompromised individuals), resulting in an incomplete immune restitution. ${ }^{18}$ Under the previous screening regimen, all asymptomatic patients with CD4 counts of less than 50/ $\mathrm{mm}^{3}$ were screened at 3 monthly intervals. The finding of Jacobson $\mathrm{et} \mathrm{al.}{ }^{19}$ was that before triple therapy only $4 \%$ of CMVR patients had CD4 counts greater than 50 cells/ $\mathrm{mm}^{3}$, but that after triple therapy $29 \%$ had CD4 counts greater than 50 cells $/ \mathrm{mm}^{3}$ and $14 \%$ had CD4 counts in excess of 100 cells $/ \mathrm{mm}^{3}$. The question is whether the CD4 count in the triple therapy era still provides a reliable indicator of the patient's immune function and, if not, what other markers should be used.

\section{Implications for the treatment of CMV and HIV disease}

We aim to delay CMVR relapse by an aggressive induction regimen, on which the patient remains on induction dosage of anti-CMV agents until all clinical activity of CMV retinitis is quiescent, rather than the standard 2-3 week induction followed by maintenance treatment. A recent study has shown that this lengthens the time to relapse. ${ }^{20}$

Recent reports of CMVR remission induced by triple therapy $^{21}$ also raise questions as to the overall management of CMV disease. Patient 22 was noted to have regressed CMVR scars in zone 3 at screening despite no history of previous CMV or treatment. The patient had been on triple therapy since the diagnosis of AIDS. He subsequently had one reactivation of CMVR in that eye, which was successfully treated. A recent study has suggested that in some patients triple therapy alone may boost the immune system sufficiently to avoid the need for anti-CMV maintenance. ${ }^{23}$ As most anti-CMV regimens are given systemically lifelong, there are potential side-effects of renal impairment and myelosuppression. ${ }^{23}$ These findings evidently raise considerations regarding both the cost and patients' quality of life.

\section{Conclusion}

It is important that in the era of triple therapy the ophthalmologist is vigilant regarding the new clinical manifestations of HIV eye disease and their implications. The full impact of these new treatment regimens has yet to be assessed.

\section{References}

1. Hoover DR, Saah AJ, Bacellar $\mathrm{H}$, et al. Clinical manifestations of AIDS in an era of Pneumocystis prophylaxis. Multicenter AIDS cohort study. N Engl J Med 1993;329:1922-6.

2. Studies of ocular complications of AIDS Research Group in collaboration with the AIDS Clinical Trial Group. Foscarnetganciclovir cytomegalovirus retinitis trial. 4. Visual outcomes. Ophthalmology 1994;101:1250-61.

3. Mouton $Y$, Alfandari S, Vallette M, et al. Impact of protease inhibitors on AIDS defining events and hospitalisations in 10 French AIDS referral centres. AIDS 1997;11:101-5.

4. Rahhal FM, Arevalo JF, Munguia D, et al. Intravitreal cidofovir for the maintenance treatment of cytomegalovirus retinitis. Ophthalmology 1996;103:1078-83.

5. Banker AS, Revalo JF, Munguia D, et al. Intraocular pressure and aqueous humour dynamics in patients with AIDS treated with intravitreal cidofovir (HPMPC) for cytomegalovirus retinitis. Am J Ophthalmol 1997;124:168-80.

6. Davis JL, Taskinhuna I, Freeman WR, Weinberg DV, Fiever WJ, Leonard RE. Iritis and hypotony after treatment with intravenous cidovir for CMV retinitis. Arch Ophthalmol 1997;115:733-7.

7. Bainbridge JWB, Raina J, Shah S. Anterior uveitis associated with CMV retinitis in AIDS: a review. Invest Ophthalmol Vis Sci (ARVO Suppl) 1998;39:S134.

8. Studies of Ocular Complications of AIDS Research Group in collaboration with the AIDS Clinical Trial Group. Foscarnetganciclovir cytomegalovirus retinitis trial. 5. Clinical features of cytomegalovirus retinitis at diagnosis. Am J Ophthalmol 1997;124:141-57.

9. Nussenblatt RB, Lane HC. Human immunodeficiency virus disease: changing patterns of ocular inflammation. Am J Ophthalmol 1998;125:374-82.

10. Magone MT, Nussenblatt RB, Whitcup SM. Elevation of laser flare photometry in patients with cytomegalovirus retinitis and AIDS. Am J Ophthalmol 1997;124:190-8.

11. Kuo IC, Kapusta MA, Rao NA. Vitritis as the primary manifestation of ocular syphilis in patients with HIV infection. Am J Ophthalmol 1998;125:306-11.

12. Margolis TP, Milner MS, Shama A, Hodge W, Seiff S. Herpes zoster ophthalmicus in patients with human immunodeficiency virus infection. Am J Ophthalmol 1998;125:285-91.

13. Silverstein BE, Smith JH, Sykes SO, et al. Cystoid macular oedema associated with cytomegalovirus retinitis in patients with the acquired immunodeficiency syndrome. Am J Ophthalmol 1998;125:412-5.

14. Alder ME, Johnson DW, Burman WJ, Johnson SC. Anterior uveitis and hypotony after intravenous cidofovir for the treatment of cytomegalovirus retinitis. Ophthalmology 1998;105:651-7.

15. Bloom PA, Sandy CJ, Migdal C, et al. Visual prognosis of AIDS patients with cytomegalovirus retinitis. Eye 1995;9:697-702.

16. Jabs DA, Bartlett JG: AIDS and ophthalmology: a period of transition. Am J Ophthalmol 1997;124:227-33.

17. Gallant J, Moore D, Richman D, et al. Incidence and natural history of CMV disease in patients with advanced HIV disease. J Infect Dis 1992;166:1223-7. 
18. Autran B, Carcelain G, Li TS, et al. Positive effects of combined antiretroviral therapy on CD4 $\mathrm{T}$ cell homeostasis and function in advanced HIV disease. Science 1997;277:112-7.

19. Jacobson MA, Zegans M, Pavan PR, et al. Cytomegalovirus retinitis after initiation of highly active antiretroviral therapy. Lancet 1997;349:1443-5.

20. Seigner SW, Holland GN, Stemien MJ, Craber M, Robinson CA, Hubbard L. The relationship between CMVR activity at the start of maintenance therapy and the time to progression. Invest Ophthalmol Vis Sci (ARVO Suppl) 1997;38:S915.

21. Reed JB, Schwab IR, Gordon J, Morse LS. Regression of cytomegalovirus retinitis associated with protease inhibitor treatment in patients with AIDS. Am J Ophthalmol 1997;124:199-205.
22. Vrabec TR, Baldassano VF, Whitcup SM. Discontinuation of maintenance therapy in patients with quiescent cytomegalovirus retinitis and elevated CD4 counts. Ophthalmology 1998;105:1259-64.

23. Studies of Ocular Complications of AIDS Research group in collaboration with the AIDS Clinical Trial Group. Morbidity and toxic effects associated with ganciclovir or foscarnet therapy in a randomised cytomegalovirus retinitis trial. Arch Intern Med 1995;155:65 74.

24. Zegans ME, Watton RC, Holland GN, et al. Transient vitreous inflammatory reactions associated with combination antiretroviral therapy in patients with AIDS and cytomegalovirus retinitis. Am J Ophthalmol 1998;125:292-300. 